ISSN: 1813-162X (Print) ; 2312-7589 (Online)
available online at: http://www.tj-es.com Tikrit Journal of Engineering Sciences

Haider S. Al-Jubair *

\section{Fareed H. Majeed}

Civil Engineering Department Basrah University Basrah

Iraq

\section{Keywords:}

Seismic load

nonlinear modal time history

isolated buildings

shear walls

irregularity of buildings

\title{
Analyses of the Base Isolated Buildings; Nonlinear Model Time History Versus Codes' Methods
}

\author{
A B S T R A C T
}

Multi-story hypothetical reinforced concrete buildings of variable geometric configurations (symmetrical, vertically irregular, horizontally irregular, with and without shear walls); with the isolated bases via high damping rubber bearing and friction pendulum systems, are analyzed using finite element method under seismic load function (North-South component of the ground motion that recorded at a site in El Centro, California in 1940) via SAP2000-V16 software. Four methods of analysis are adopted. The accuracy of the nonlinear model time history is compared with that recommended by the international codes, namely; nonlinear direct integration, equivalent lateral force, and response spectrum methods. The bilinear hysteretic model of base isolation system and the Rayleigh damping framework for superstructure are adopted. The results support the powerful nonlinear model time history analysis, due to the negligible deviations from those predicted by the robust nonlinear direct integration method. The response spectrum method is proved to be more reliable than the equivalent lateral force method which over predicts the displacement and rotation profiles for the isolated buildings.

(c) 2017 TJES, College of Engineering, Tikrit University

DOI: http://dx.doi.org/10.25130/tjes.24.3.08

تحليل أبنية معزولة زلزالياً: تأريخ زمني مشروط لا خطي ضد طرق المدونات

الخلاصة

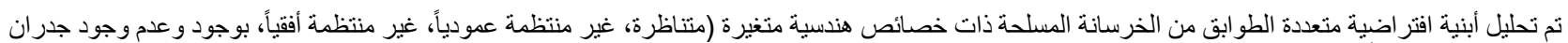

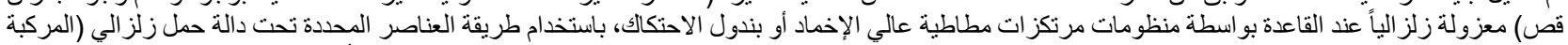

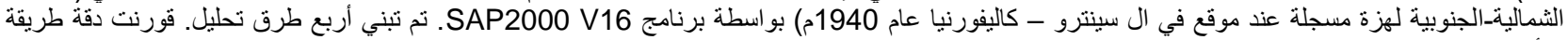

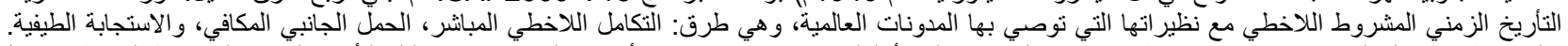

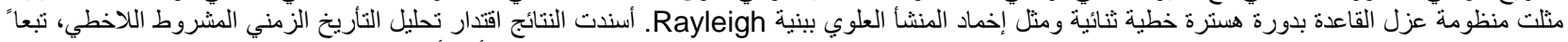

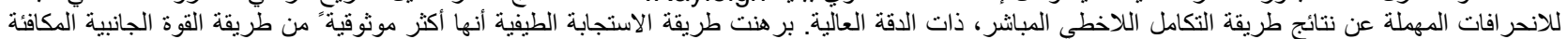

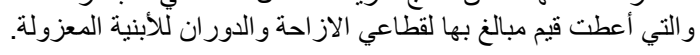

\section{INTRODUCTION}

The concept of passive base isolation has two basic types of isolation systems. These two basic types are

1- The system that uses an elastomeric bearing. In this approach, the building is decoupled from the horizontal components of the earthquake ground motion by interposing a layer with low horizontal stiffness between the structure and the foundation.

2- The system that uses sliding. In this approach, the system is limiting the transfer of shear across the isolation interface by using sliders or rollers between the structure and the foundation

This paper investigates the accuracy of the nonlinear model and provides time history analysis for the isolated buildings compared with the code methods. The two 
isolator types are representative of the sliding and elastomeric systems which are represented by the Friction Pendulum System (FPS) and the High Damping Rubber Bearings (HDRB), respectively. The skeleton of the studied cases is illustrated in Table 1.

\section{Table 1}

Skeleton of the studied cases.

\begin{tabular}{|c|c|c|c|}
\hline $\begin{array}{c}\text { Case } \\
\text { study } \\
\text { No. }\end{array}$ & Type of base & \begin{tabular}{|c|} 
Type of \\
reinforced \\
concrete \\
superstructure
\end{tabular} & $\begin{array}{c}\text { Method of } \\
\text { analysis }\end{array}$ \\
\hline \multirow{4}{*}{1} & \multirow{2}{*}{$\begin{array}{l}\text { High damping } \\
\text { rubber bearing }\end{array}$} & \multirow{4}{*}{$\begin{array}{l}\text { Symmetrical } \\
\text { building }\end{array}$} & $\begin{array}{c}\text { Direct } \\
\text { integration }\end{array}$ \\
\hline & & & $\begin{array}{l}\text { Equivalent } \\
\text { lateral force }\end{array}$ \\
\hline & \multirow{2}{*}{$\begin{array}{l}\text { Friction } \\
\text { pendulum }\end{array}$} & & $\begin{array}{r}\text { Response } \\
\text { spectrum }\end{array}$ \\
\hline & & & $\begin{array}{c}\text { Modal time } \\
\text { history }\end{array}$ \\
\hline \multirow{4}{*}{2} & \multirow{2}{*}{$\begin{array}{l}\text { High damping } \\
\text { rubber bearing }\end{array}$} & \multirow{4}{*}{$\begin{array}{l}\text { Symmetrical } \\
\text { building with } \\
\text { shear walls }\end{array}$} & $\begin{array}{c}\text { Direct } \\
\text { integration }\end{array}$ \\
\hline & & & $\begin{array}{l}\text { Equivalent } \\
\text { lateral force }\end{array}$ \\
\hline & \multirow{2}{*}{$\begin{array}{l}\text { Friction } \\
\text { pendulum }\end{array}$} & & $\begin{array}{l}\text { Response } \\
\text { spectrum }\end{array}$ \\
\hline & & & $\begin{array}{c}\text { Modal time } \\
\text { history }\end{array}$ \\
\hline \multirow{4}{*}{3} & \multirow{2}{*}{$\begin{array}{l}\text { High damping } \\
\text { rubber bearing }\end{array}$} & \multirow{4}{*}{$\begin{array}{c}\text { Vertically } \\
\text { irregular building }\end{array}$} & $\begin{array}{c}\text { Direct } \\
\text { integration }\end{array}$ \\
\hline & & & $\begin{array}{l}\text { Equivalent } \\
\text { lateral force }\end{array}$ \\
\hline & \multirow{2}{*}{$\begin{array}{l}\text { Friction } \\
\text { pendulum }\end{array}$} & & $\begin{array}{r}\text { Response } \\
\text { spectrum }\end{array}$ \\
\hline & & & $\begin{array}{c}\text { Modal time } \\
\text { history }\end{array}$ \\
\hline \multirow{4}{*}{4} & \multirow{2}{*}{$\begin{array}{l}\text { High damping } \\
\text { rubber bearing }\end{array}$} & \multirow{4}{*}{$\begin{array}{l}\text { Vertically } \\
\text { irregular } \\
\text { building with } \\
\text { shear walls }\end{array}$} & $\begin{array}{c}\text { Direct } \\
\text { integration }\end{array}$ \\
\hline & & & $\begin{array}{l}\text { Equivalent } \\
\text { lateral force }\end{array}$ \\
\hline & \multirow{2}{*}{$\begin{array}{l}\text { Friction } \\
\text { pendulum }\end{array}$} & & $\begin{array}{r}\text { Response } \\
\text { spectrum }\end{array}$ \\
\hline & & & $\begin{array}{c}\text { Modal time } \\
\text { history }\end{array}$ \\
\hline \multirow{4}{*}{5} & \multirow{2}{*}{$\begin{array}{l}\text { High damping } \\
\text { rubber bearing }\end{array}$} & \multirow{4}{*}{$\begin{array}{c}\text { Horizontally } \\
\text { irregular building }\end{array}$} & $\begin{array}{c}\text { Direct } \\
\text { integration }\end{array}$ \\
\hline & & & $\begin{array}{c}\text { Equivalent } \\
\text { lateral force }\end{array}$ \\
\hline & \multirow{2}{*}{$\begin{array}{l}\text { Friction } \\
\text { pendulum }\end{array}$} & & $\begin{array}{r}\text { Response } \\
\text { spectrum }\end{array}$ \\
\hline & & & $\begin{array}{c}\text { Modal time } \\
\text { history }\end{array}$ \\
\hline \multirow{4}{*}{6} & \multirow{2}{*}{$\begin{array}{l}\text { High damping } \\
\text { rubber bearing }\end{array}$} & \multirow{4}{*}{$\begin{array}{l}\text { Horizontally } \\
\text { irregular } \\
\text { building with } \\
\text { shear walls }\end{array}$} & $\begin{array}{c}\text { Direct } \\
\text { integration }\end{array}$ \\
\hline & & & $\begin{array}{l}\text { Equivalent } \\
\text { lateral force }\end{array}$ \\
\hline & \multirow{2}{*}{$\begin{array}{l}\text { Friction } \\
\text { pendulum }\end{array}$} & & $\begin{array}{r}\text { Response } \\
\text { spectrum }\end{array}$ \\
\hline & & & $\begin{array}{c}\text { Modal time } \\
\text { history }\end{array}$ \\
\hline
\end{tabular}

\section{MODELING THE ISOLATED BUILDINGS}

The buildings are modeled using the finite element method and using SAP2000 program software. A directional material model is used for superstructure of the building, in which uncoupled stress-strain behavior is modeled for one or more stress-strain components. When the state of stress or strain reaches a critical value, the concrete can start failing by fracturing. The fracture of concrete can occur in two different forms. One is by cracking, under tensile type of stress states, and the other by crushing under compressive type of stress states.

The force-deformation behavior of the two systems of the isolators is modeled as non-linear hysteretic represented by the bi-linear model as shown in Fig. 1. The isolator is modeled using six springs. The springs for the three deformations: axial, shear in the $\mathrm{x}-\mathrm{z}$ plane, and pure bending in the $\mathrm{x}-\mathrm{z}$ plane as shown in Fig. 2. The hysteretic models for bearings is used to account for all the energy dissipation and the viscous damping using the Rayleigh damping framework is used for the superstructure.

The geometric configurations of the superstructures are shown in Figs. 3 and 5. A 150mm thick slab and $150 \mathrm{~mm}$ thick shear wall are considered with $(400 \mathrm{~mm} \times 600 \mathrm{~mm})$ beam of typical sections and column size of $(600 \mathrm{~mm} \times 600$ $\mathrm{mm})$.

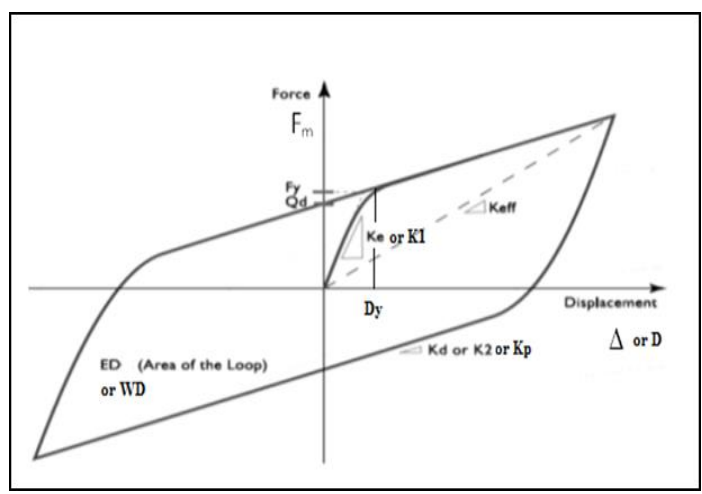

Fig. 1. Parameters of basic hysteresis loop of an isolator for bilinear modeling [1].

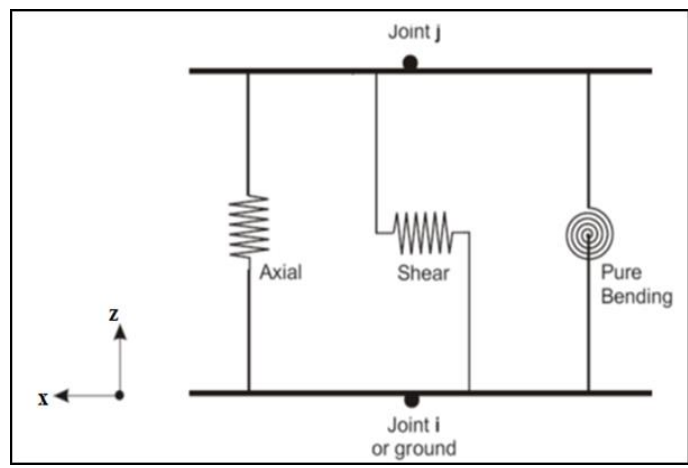

Fig. 2. Three of the six independent springs in a Link/Support element [2].

\section{APPLIED LOADS}

The reinforced concrete buildings are analyzed for dead, live, and earthquake functional loads. The minimum design dead load on each floor consists of loads due to floor slab, beams, columns and portion walls. The floor live load is taken as $3 \mathrm{kN} / \mathrm{m}^{2}$ and the roof live load is taken as 1.5 $\mathrm{kN} / \mathrm{m}^{2}$. The North-South component of the ground motion recorded at a site in El Centro, California in 1940, shown in Fig. 6, is applied to the building. All of the dead load and only $25 \%$ of the live load is considered in the seismic analysis [3]. 


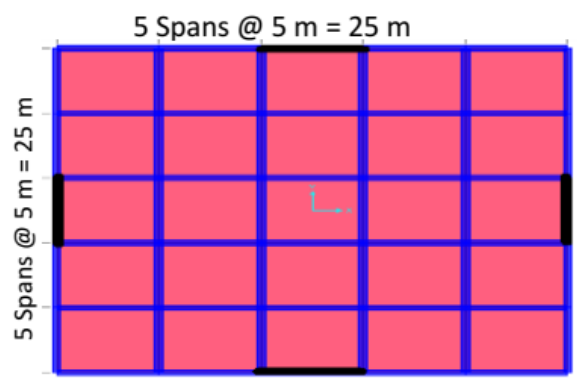

5 Spans @ $5 \mathrm{~m}=25 \mathrm{~m}$

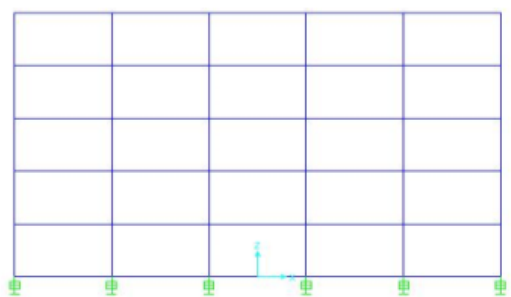

Fig. 3. Symmetrical building.

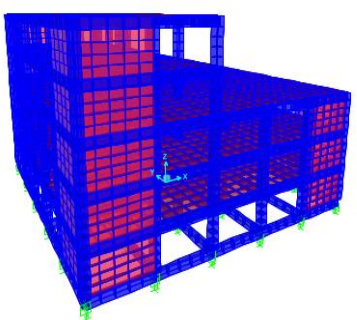

a. $3 \mathrm{D}$ view

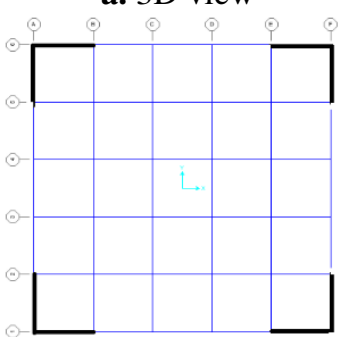

b. Plan

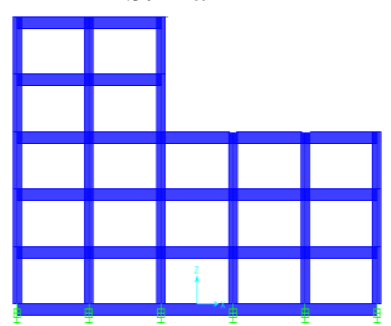

c. Section

Fig. 4. Vertically irregular building.

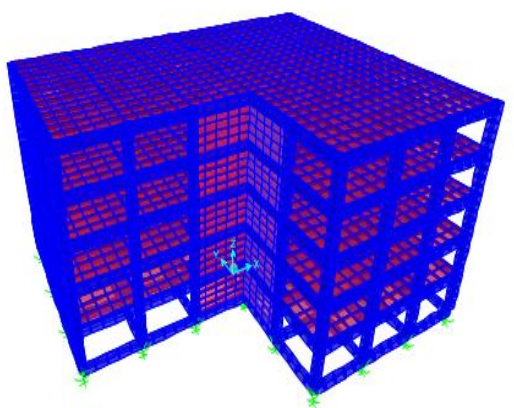

a. $3 \mathrm{D}$ view

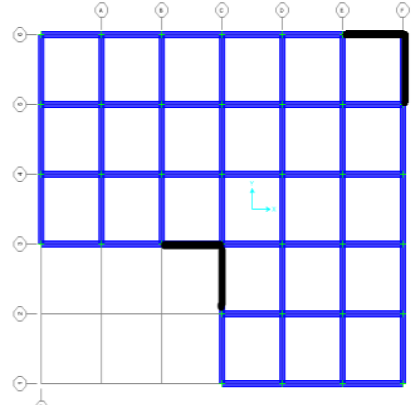

b. Plan

Fig. 5. Horizontally irregular building.

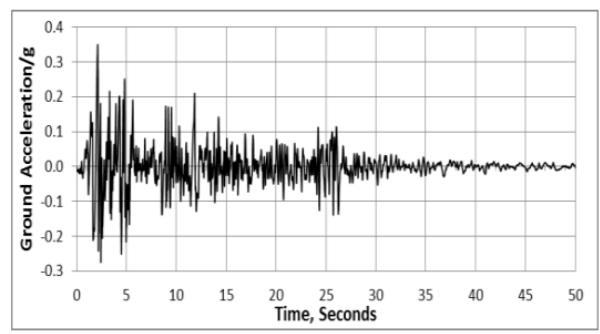

Fig. 6. El Centro, California in 1940 earthquake [4].
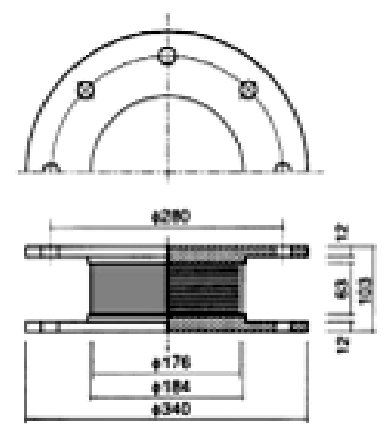

a. High damping rubber bearing used in the earthquake simulator tests with dimensions in $\mathrm{mm}$ [6].

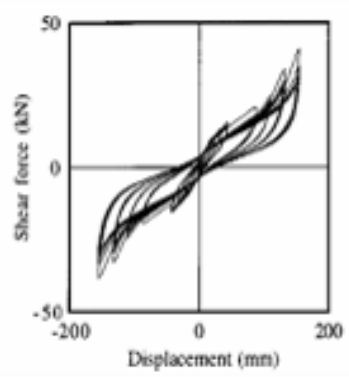

b. Corresponding force-deformation hysteresis for HDRB [6].

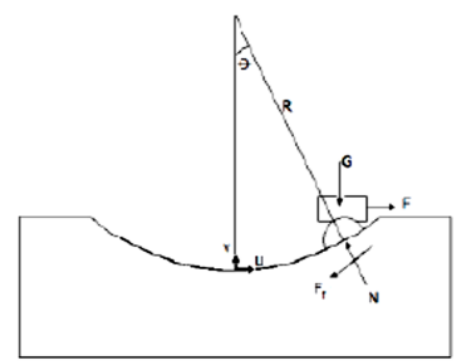

c. Mechanism of the friction pendulum system [7]. Fig. 7. The characteristics of isolation systems. 


\section{DESIGN OF BASE ISOLATORS}

The isolators are designed according to the procedures that described in the UBC-97 [5]. The characteristics of the high damping rubber bearing system are illustrated in Fig. 7(a) and (b) whereas, the mechanism of friction pendulum system is shown in Fig. 7(c).

The characteristics of the superstructure materials and the design parameters of the isolation systems are summarized in Tables 2 and 3, respectively.

Table 2

The superstructure material properties

\begin{tabular}{|c|c|c|c|}
\hline Symbol & description & unit & Value \\
\hline$f_{c}^{\prime}$ & $\begin{array}{l}\text { The cylinder ultimate } \\
\text { compression strength } \\
\text { of concrete }\end{array}$ & $\begin{array}{l}\mathrm{N} / \mathrm{m} \\
\mathrm{m}^{2}\end{array}$ & 25 \\
\hline$f_{y}$ & $\begin{array}{l}\text { The yield stress of } \\
\text { steel reinforcement }\end{array}$ & $\begin{array}{l}\mathrm{N} / \mathrm{m} \\
\mathrm{m}^{2}\end{array}$ & 410 \\
\hline$E_{c}$ & $\begin{array}{l}\text { The modulus of } \\
\text { elasticity of concrete }\end{array}$ & $\begin{array}{l}\mathrm{N} / \mathrm{m} \\
\mathrm{m}^{2}\end{array}$ & 23000 \\
\hline$\rho_{c}$ & The concrete density & $\mathrm{kg} / \mathrm{m}^{3}$ & 2400 \\
\hline$v_{c}$ & $\begin{array}{l}\text { Poisson's ratio of } \\
\text { concrete }\end{array}$ & --- & 0.15 \\
\hline
\end{tabular}

Table 3

Design parameters of the isolators.

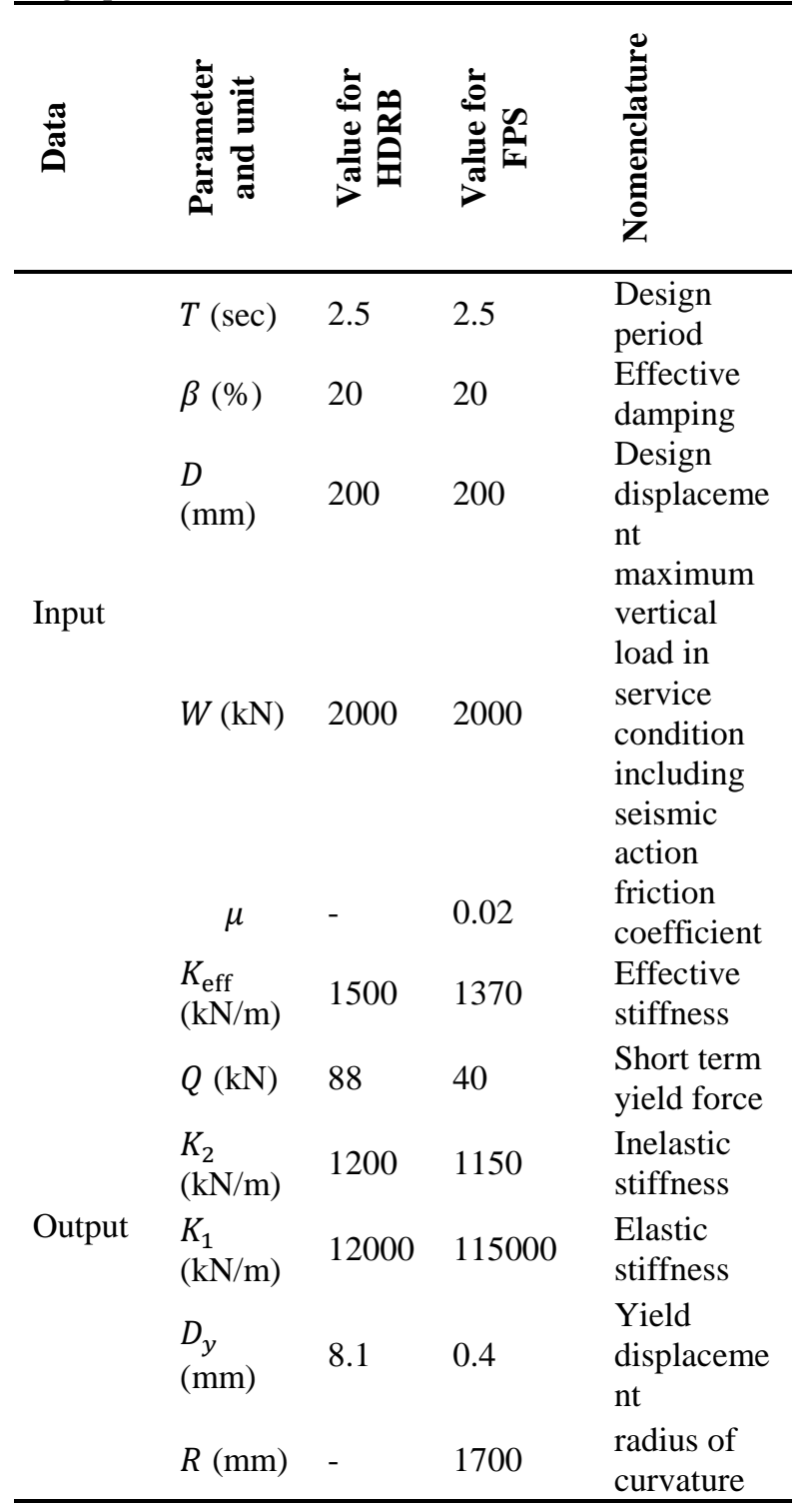

\subsection{Codes' Analyses Methods}

The codes (IBC2012 [3], UBC97 [7] and FEMA 273 [8]) provide three methods to analyze base isolated buildings, as mentioned below:

1- Equivalent lateral force method.

2- Response spectrum analysis.

3- Nonlinear direct integration method.

Since the nonlinear direct integration method can be used for all isolation systems regardless of height, size, geometry, location, and nonlinearity and gives an accurate solution to the dynamic response isolated base buildings, it will be considered as a reference for the comparison.

\subsection{Equivalent lateral force method}

The following steps summarize this analysis procedure:

1- The components and elements above the isolation system should be designed and constructed to resist a minimum lateral seismic force $\left(\mathrm{V}_{\mathrm{s}}\right)$.

$V_{S}=\frac{K_{D \max } D}{R_{1}}$

where:

$K_{\text {Dmax }}$ : isolator stiffness.

$D \quad$ : design displacement of the isolator.

$R_{1}$ : seismic load reduction factor for isolated building.

While FEMA 273 and IBC2000 define the reduction factor $\left(R_{1}\right)$, as three-eighths of the $(R)$, factor for the seismic force-resisting system, the UBC97 give $\left(R_{1}\right)$ directly based on the type of the lateral force resisting system that used in the building above the isolation system.

2- The total force should be distributed over the height of the building above the isolation interface as follows:

$F_{x}=\frac{V_{S} W_{x} h_{x}}{\sum_{i=1}^{n} W_{i} h_{i}}$

where:

$F_{\mathrm{x}}$ : shear force at level $\mathrm{x}$.

$h_{\mathrm{i}}$ : height above the base to level $\mathrm{i}$.

$h_{\mathrm{x}}$ : height above the base to level $\mathrm{x}$.

$W_{\mathrm{x}}$ : portion of total load that is located at or assigned to level $\mathrm{x}$.

$W_{\mathrm{i}}$ : portion of total load that is located at or assigned to level i.

\subsection{Response Spectrum Analysis}

The response spectrum technique is really a simplified special case of modal analysis. The modes of vibration are determined in period and shape using usual way. The maximum response magnitudes corresponding to each mode are found by reference to a response spectrum. The design earthquake spectrum should be used to calculate the total design displacement of the isolation system and the lateral forces and displacements of the isolated building. For comparison purposes, the El Centro earthquake response spectrum is shown in Fig. 8.

\subsection{Nonlinear Modal Time History Analysis}

For the isolated building, the superstructure behaves (nearly) as a rigid body and the main effect of nonlinearity 
belongs to the isolator devices of buildings. Therefore, the nonlinearity of the isolators has very important effect on the behavior of the buildings.

In this paper, the dynamic analysis of the buildings with nonlinear isolators and linear superstructure is considered and the results are compared with their corresponding values the obtained from the nonlinear direct integration method.

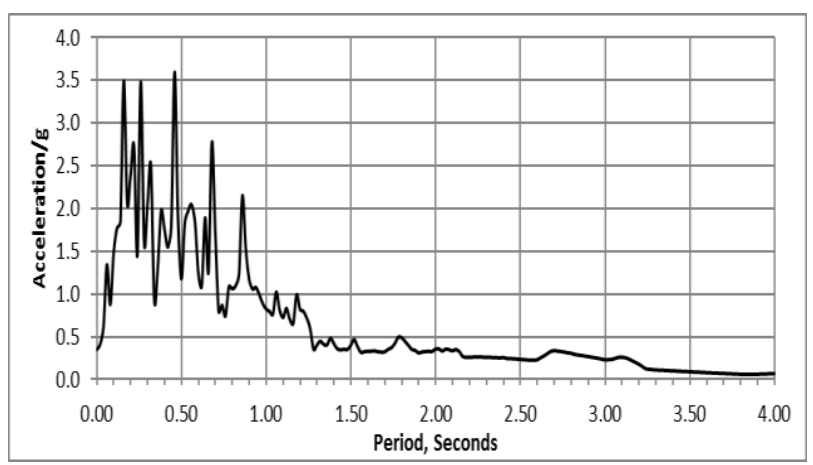

Fig. 8. The El Centro earthquake response spectrum.

\section{RESULTS}

Fig. 9 shows the displacement at center of mass in each story of the isolated buildings, as determined by the equivalent lateral force method (EQ), response spectrum analysis (RS), and nonlinear direct integration method (DI). Fig. 10 shows the rotation at center of mass in each story for irregular isolated buildings. For the six case studies, the response spectrum method is proved to be more reliable than the equivalent lateral force method which over predicts the displacement and rotation profiles for the isolated buildings.

For the first case study, Fig. 11, a shows comparison between nonlinear modal time history (NMTH) and nonlinear direct integration (DI) methods of friction pendulum base of isolated building in terms of total base. shear, maximum displacement and maximum acceleration. The differences in results are negligible and the nonlinear modal time history analysis is proved to be the most accurate among the methods provided by the codes.

Table 4

Percentage increase in total base shear of building analyses by NMTH from DI

\begin{tabular}{lll}
\hline $\begin{array}{l}\text { Case Study } \\
\text { No. }\end{array}$ & $\begin{array}{l}\text { Isolation } \\
\text { Type }\end{array}$ & $\begin{array}{l}\text { Increase } \\
(+) \%\end{array}$ \\
\hline \multirow{2}{*}{1} & FPS & +1.2 \\
& HDRB & +1.3 \\
2 & FPS & +0.9 \\
& HDRB & +1.2 \\
3 & FPS & +1.1 \\
& HDRB & +1.4 \\
4 & FPS & +0.9 \\
& HDRB & +1.1 \\
5 & FPS & +0.7 \\
& HDRB & +0.9 \\
6 & FPS & +0.8 \\
& HDRB & +0.9 \\
\hline
\end{tabular}

Tables $4-6$, show the differences percentage in total base shear, maximum acceleration and maximum displacement that corresponding to the nonlinear modal time history analysis compared with the nonlinear direct integration method, for the six case studies.

The results support the powerful nonlinear modal time history analysis, due to a negligible deviation from those predicted by the robust nonlinear direct integration method.

\section{Table 5}

Percentage increase in maximum displacement of building analyses by NMTH from DI.

\begin{tabular}{lll}
\hline $\begin{array}{l}\text { Case study } \\
\text { No. }\end{array}$ & $\begin{array}{l}\text { Isolation } \\
\text { Type }\end{array}$ & $\begin{array}{l}\text { Increase } \\
(+) \%\end{array}$ \\
\hline 1 & FPS & +0.5 \\
& HDRB & +0.2 \\
2 & FPS & +0.4 \\
& HDRB & +0.3 \\
3 & FPS & +0.7 \\
& HDRB & +0.3 \\
4 & FPS & +0.5 \\
& HDRB & +0.4 \\
5 & FPS & +0.6 \\
& HDRB & +0.3 \\
6 & FPS & +0.6 \\
& HDRB & +0.2 \\
\hline
\end{tabular}

Table 6

Percentage decrease in response of maximum acceleration of building analyses by NMTH from DI.

\begin{tabular}{lll}
\hline $\begin{array}{l}\text { Case study } \\
\text { No. }\end{array}$ & $\begin{array}{l}\text { Isolation } \\
\text { Type }\end{array}$ & $\begin{array}{c}\text { Decrease } \\
(-)\end{array}$ \\
\hline 1 & FPS & -1.3 \\
& HDRB & -1.1 \\
2 & FPS & -0.8 \\
& HDRB & -0.7 \\
3 & FPS & -1.2 \\
& HDRB & -1.4 \\
4 & FPS & -1.3 \\
& HDRB & -1.3 \\
5 & FPS & -1.2 \\
& HDRB & -0.9 \\
6 & FPS & -0.8 \\
& HDRB & -1.1 \\
\hline
\end{tabular}

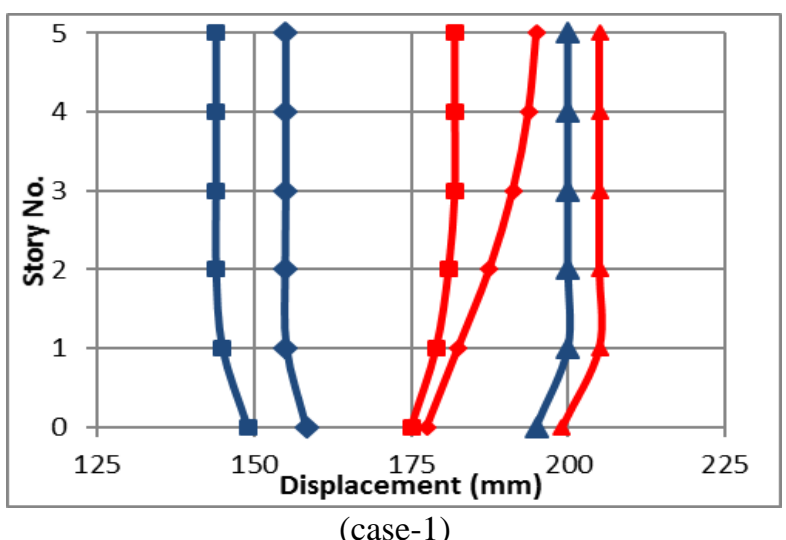

Fig. 9. Continues 


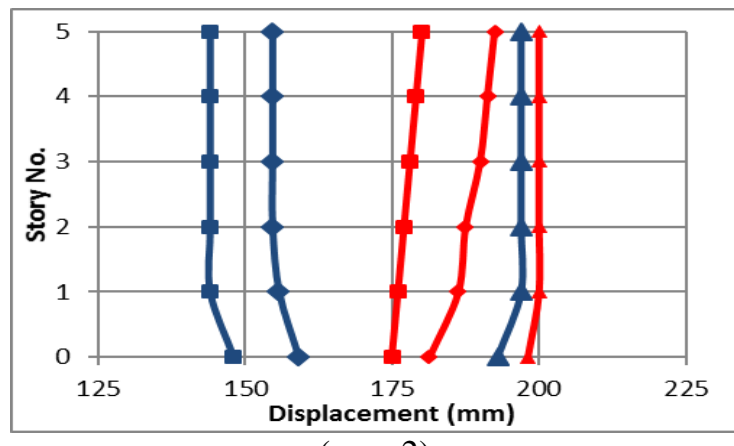

(case-2)

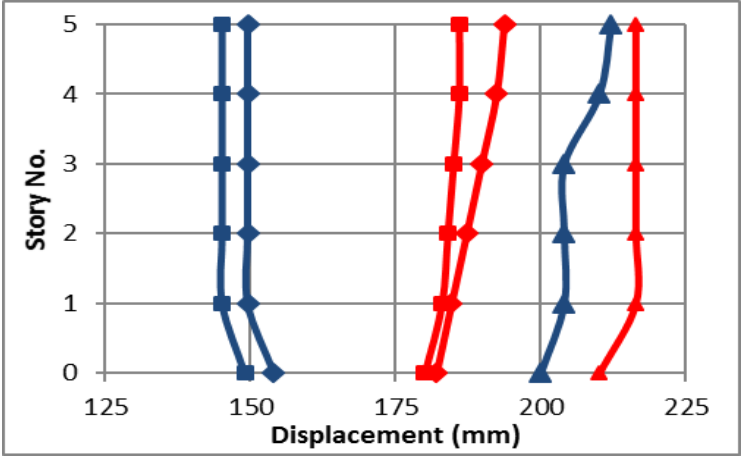

(case-3)

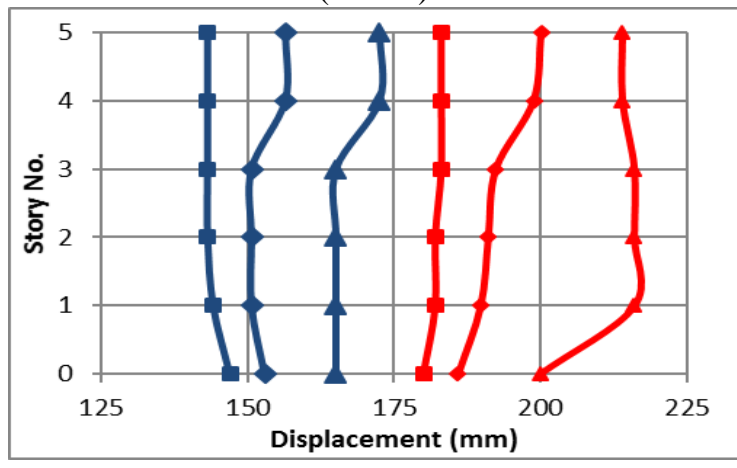

(case-4)

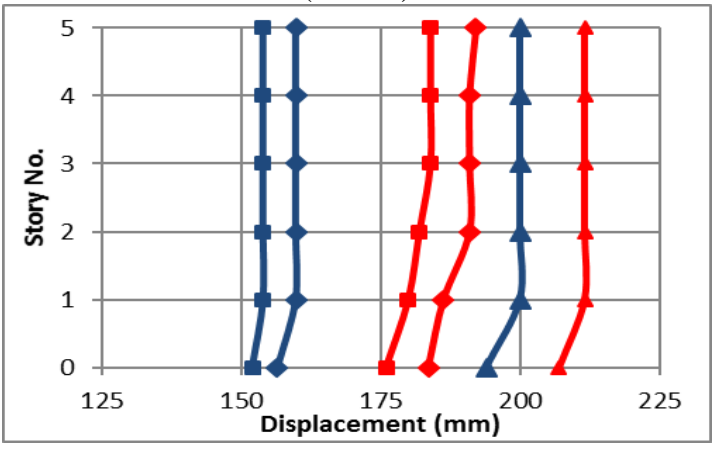

(case-5)

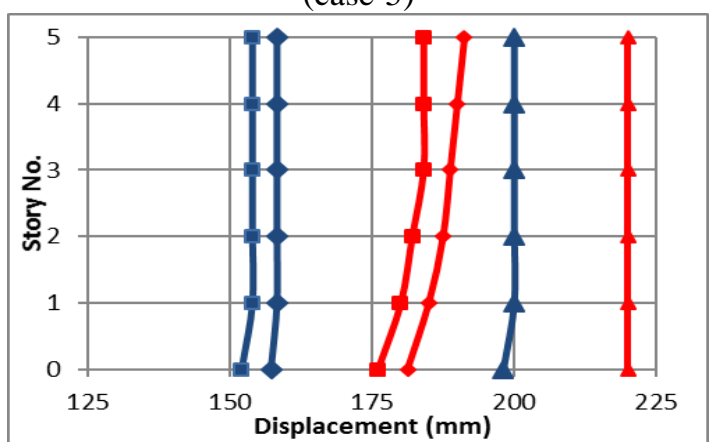

(case-6)

$\simeq$ FP-DI $\longrightarrow F P-E Q-F P-R S$

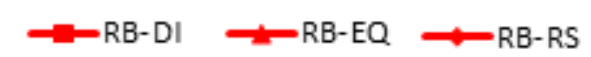

Fig. 9. The displacement at center of mass.

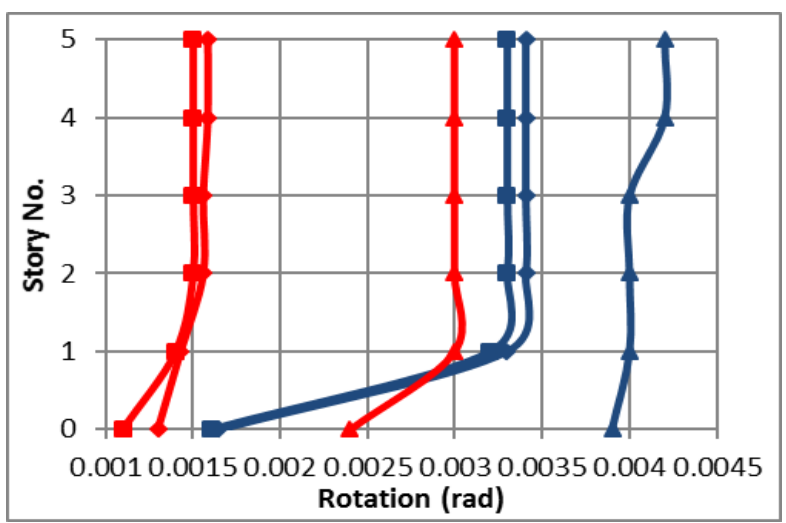

(case-3)

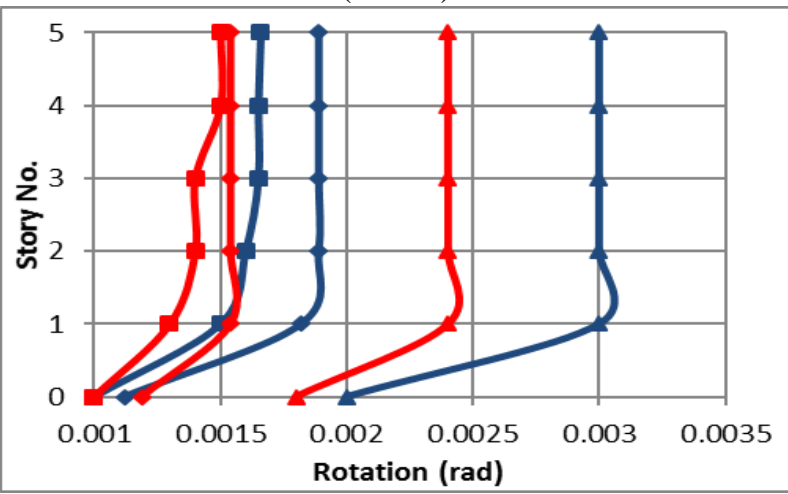

(case-4)

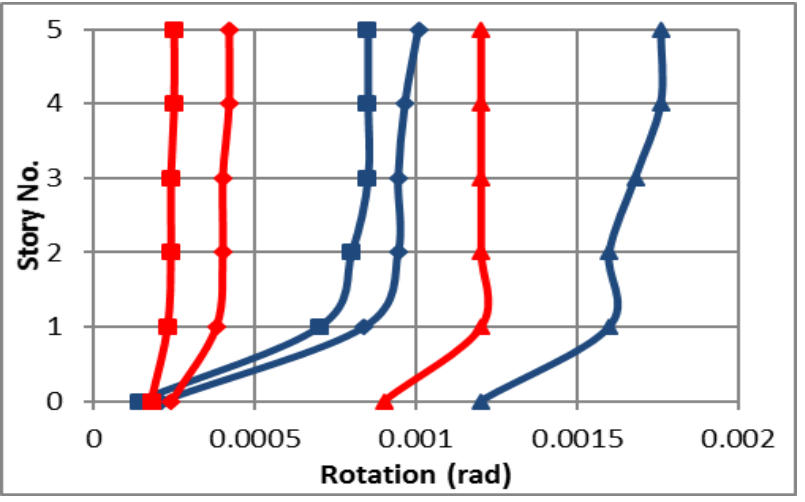

(case-5)

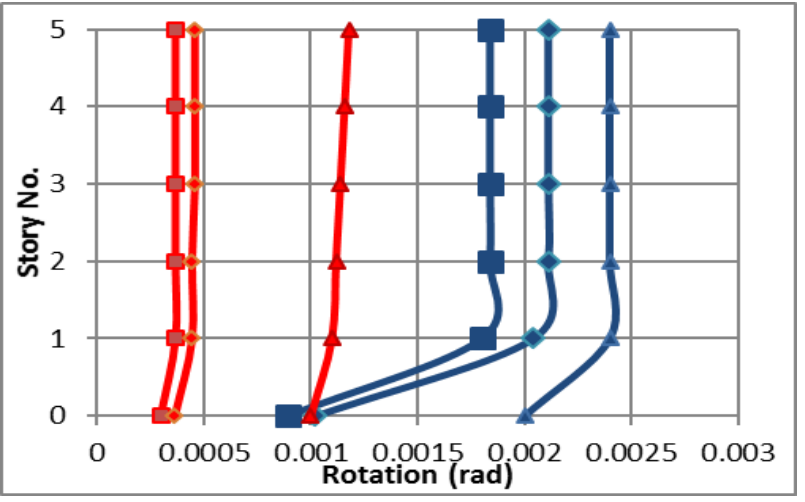

(case-6)

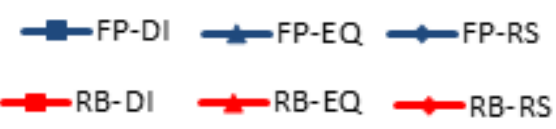

Fig. 10. The rotation at center of mass. 


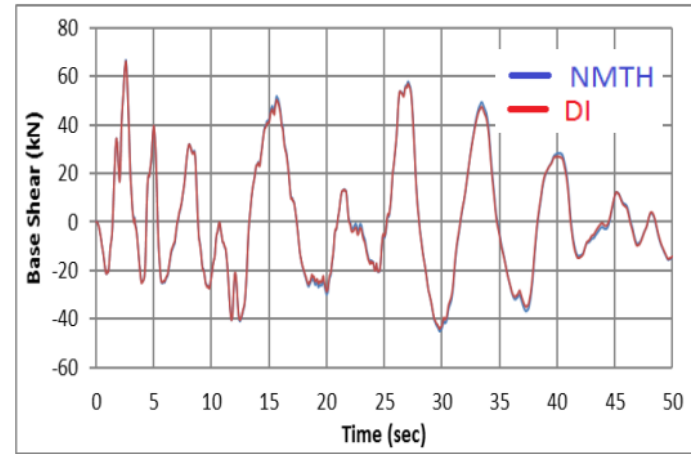

Base shear with time

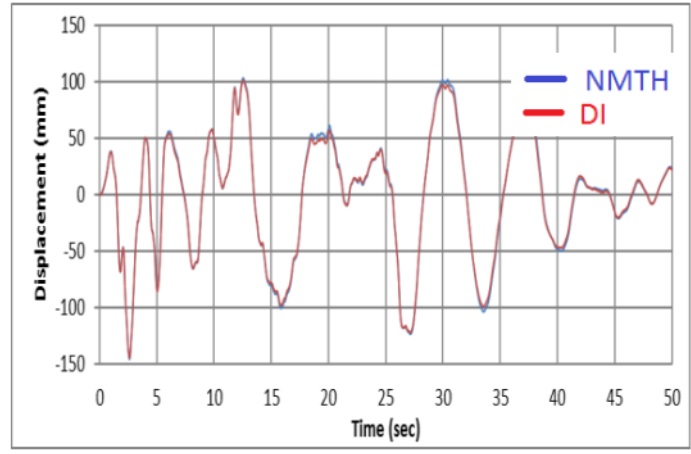

Displacement with time

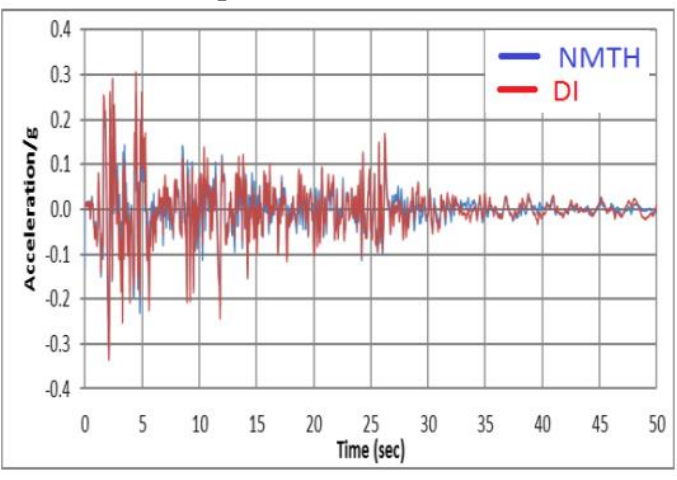

Acceleration with time

Fig. 11. Comparison between NMTH and DI for FP (case-1).

\section{CONCLUSIONS}

1. The nonlinear modal time history gives an identical result to the robust nonlinear direct integration method, in a record run time for all cases, the max deviation is $1.4 \%$ which is negligible.

2. The response spectrum analysis proved to be more reliable than the equivalent lateral force method which is over predicts the displacement and rotation profiles for the isolated buildings and overestimates the response compared with nonlinear direct integration method. The max deviation for RS method is $30 \%$ whereas it is $170 \%$ for EQ method.

3. The irregularity of the building (vertically and horizontally) that affected the accuracy of the response spectrum analysis and equivalent lateral force method compared with the direct integration method. For RS method, the max. deviation without irregularity is $15 \%$ and with irregularity is $30 \%$ and for EQ method, the max deviation without irregularity is $45 \%$ and with irregularity is $170 \%$.
4. The inclusion of shear walls has variable effect on the accuracy of the response spectrum analysis and equivalent lateral force method. For RS method, the max deviation without irregularity is $10 \%$ and with irregularity is $30 \%$ and for EQ method, the $\max$ deviation without irregularity is $30 \%$ and with irregularity is $170 \%$.

5. The building irregularity and inclusion of shear walls have a negligible effect on the accuracy of the nonlinear modal time history analysis.

\section{REFERENCES}

[1] Jena K. Passive vibration control of framed structures by base isolation method using lead rubber bearing. Master of Technology in Structural Engineering, Thesis. National Institute of Technology. Rourkela; 2006.

[2] CSI Analysis Reference Manual for SAP2000, ETABS, SAFE and CSI Bridge; 2011.

[3] International Building Code 2012. International code council. INC. USA; 2011.

[4] Chopra A. Dynamics of structures, theory and applications to earthquake engineering. 3rd edition, Upper Saddle River: New Jersey; 2007.

[5] Naeim F and Kelly J. Design of seismic isolated structures: from theory to practice. John Wiley \& Sons, Inc; 1999.

[6] Higashino M and Okamoto S. Response control and seismic isolation of buildings. Taylor and Francis: USA; 2006.

[7] Uniform Building Code. Structural engineering design provisions, USA;1997.

[8] Federal Emergency Management Agency (FEMA 273). Building Seismic Safety Council, Washington, D.C;1997

frequency magnetic fields. Mutat Research 1998; 410 (2): 167-183.

[5] Ahlbom A, Cardis E, Green A, Linet M, Savitz D, Swerdlow A. (ICINRP) ICIRP International commission on non-Ionizing radiation protection standing committee on epidemiology: Review of the epidemiology literature on EMF and health. Environmental Health Perspectives 2001; 109 (6): 911-933.

[6] Delaplace LR, Reilly JP. Electric and magnetic field coupling from high voltage AC power transmission lines-classification of short-term effects on people. IEEE Transactions on Power Apparatus and Systems 1978; PAS-97: 2243-2252.

[7] Baris D, Armstrong BG, Deadman J, Thériault G. A mortality study of elec. utility workers. Occupational and Environmental Medicine 1996; 53: 25-31.

[8] Davanipour Z, Sobel E, Bowman JD, Qian Z, Will AD. Amyotrophic lateral sclerosis and occupational exposure to elctromagnetic fields. Bioelectromagnetics 1997; 18: 28-35.

[9] Matthew NO. Elements of Electromagnetic: Sadiku; 2005. 